\title{
Regulation of Glucose Transporter-specific mRNA Levels in Rat Adipose Cells with Fasting and Refeeding

\author{
Implications for In Vivo Control of Glucose Transporter Number
}

\author{
Barbara B. Kahn, ${ }^{*}$ Samuel W. Cushman, ${ }^{*}$ and Jeffrey S. Flier ${ }^{*}$ \\ *The Charles A. Dana Research Institute and the Harvard-Thorndike Laboratory of Beth Israel Hospital, Department of Medicine, \\ Beth Israel Hospital and Harvard Medical School, Boston, Massachusetts 02215; and ${ }^{\ddagger}$ Experimental Diabetes, Metabolism \\ and Nutrition Section, Molecular, Cellular and Nutritional Endocrinology Branch, National Institute of Diabetes \\ and Digestive and Kidney Diseases, National Institutes of Health, Bethesda, Maryland 20892
}

\begin{abstract}
Fasting in the rat is associated with a rapid and progressive decrease in insulin-stimulated glucose transport activity in adipose cells, which is not only restored to normal, but increased transiently to supranormal levels by refeeding. The mechanisms for these changes in glucose transport activity appear to involve alterations in both glucose transporter number and intrinsic activity (glucose turnover number). In this study, we use the human hepatoma Hep G2 glucose transporter complementary DNA clone to examine the molecular basis for these alterations. Extractable RNA per adipose cell is decreased $35 \%$ with $3 \mathrm{~d}$ of fasting and increased to $182 \%$ of control with $6 \mathrm{~d}$ of refeeding after $2 \mathrm{~d}$ of fasting. This parallels changes in adipose cell intracellular water, so that total RNA/ water space remains relatively constant. When the changes in total RNA/cell are taken into account, Northern and slot blot analyses with quantitative densitometry reveal a $36 \%$ decrease in specific glucose transporter mRNA level in cells from the fasted rats. The mRNA level in cells from the fasted/refed rats is restored to normal. These observations correlate closely with previous measurements of glucose transporter number in adipose cell membrane fractions using cytochalasin $B$ binding and Western blotting. The levels of specific mRNAs for tubulin and actin on a per cell basis show similar but more dramatic changes and mRNAs encoding several differentiation-dependent adipose cell proteins are also significantly affected. Thus, the levels of mRNA for multiple adipose cell genes are affected by fasting and refeeding. In particular, this demonstrates that in vivo metabolic alterations can influence the level of a glucose transporter mRNA in adipose cells. This may have implications for the regulation of glucose transporter number and glucose transport activity.
\end{abstract}

\section{Introduction}

Marked variations in glucose transport and metabolism occur with fasting and refeeding in rats (1-4) and humans (5).

Address reprint requests to Dr. Kahn, Diabetes Unit, Beth Israel Hospital, 330 Brookline Avenue, Boston, MA 02215.

Received for publication 24 February 1988 and in revised form 8 August 1988.

J. Clin. Invest.

(c) The American Society for Clinical Investigation, Inc.

$0021-9738 / 89 / 01 / 0199 / 06 \$ 2.00$

Volume 83, January 1989, 199-204
Among the major cellular adaptations to fasting in the rat is a rapid, progressive, and reversible decrease in the ability of adipose cells to transport glucose in response to insulin $(1,4)$. Refeeding not only reverses this insulin resistance but results in glucose transport that is hyperresponsive to insulin (4). The mechanism for the insulin-resistant glucose transport seen with fasting in the rat involves a depletion of intracellular glucose transporters so that fewer are available to be translocated to the plasma membrane in response to insulin. Refeeding restores to normal both the number of glucose transporters in the low density microsomal pool in the basal state and their translocation to the plasma membrane in response to insulin. A transient doubling of the maximum velocity $\left(V_{\max }\right)$ for glucose transport is observed with $6 \mathrm{~d}$ of refeeding and cannot be explained by changes in the number of glucose transporters per cell or in the apparent affinity $\left(K_{\mathrm{m}}\right)$ of the transporter for glucose; an increase in glucose transporter intrinsic activity (glucose turnover number, moles of glucose/glucose transporter/ unit time) has therefore been proposed (4). Alterations in glucose transporter intrinsic activity have previously been demonstrated in association with other altered metabolic states (6-8), as well as in vitro incubation of adipose cells with lipolytic and antilipolytic agents (9-11).

The decrease in glucose transporter number seen with fasting and restoration to control levels seen with refeeding could result from changes in the rate of synthesis and/or degradation of the glucose transporter protein. The synthesis rate, in turn, could be controlled by the rate of transcription of the glucose transporter gene, the stability of the transporter mRNA, the translation of the mRNA into the glucose transporter protein or posttranslational modification of the protein. The current study was designed to determine whether the changes in adipose cell glucose transporter number observed with fasting and refeeding in the rat are controlled through changes at the level of the glucose transporter mRNA.

To investigate this, we used the glucose transporter complementary DNA (cDNA) clone, which was obtained by screening a cDNA library prepared from the Hep G2 human hepatoma cell line (12) with a polyclonal antibody directed against the human erythrocyte facilitated diffusion glucose carrier. This cDNA encodes a protein which is $97.6 \%$ homologous with the glucose transporter encoded by a cDNA isolated from a rat brain library (13). These highly homologous cDNAs have recently been shown to hybridize under stringent conditions with a single 2.8 kilobase (kb) mRNA in multiple rat and human tissues including adipose cells and notably excluding normal liver $(13,14)$. These observations suggest that a glucose transporter species present in Hep G2 cells, brain, and adipose cells is highly homologous at both the gene and protein level. 
Using this Hep G2/brain cDNA probe we find a close correlation between glucose transporter mRNA levels and the number of glucose transporters as previously determined by cytochalasin B binding in adipose cells from fasted and refed rats (4) (Fig. 5).

\section{Methods}

Animals and experimental design. Male Sprague-Dawley rats (CD strain; Charles River Breeding Laboratories, Wilmington, MA) were received at body weights ranging from 130 to $140 \mathrm{~g}$ and maintained with ad lib. feeding (standard NIH chow) for several days before initiation of the experimental period. One group of rats was fasted for $2 \mathrm{~d}$, starting between 8 and $9 \mathrm{AM}$ and then refed for $6 \mathrm{~d}$. Another group was fed ad lib. for the first $5 \mathrm{~d}$ of the experimental period and then fasted for $3 \mathrm{~d}$. Control animals were fed ad lib. for the entire experimental period. All animals were killed by cervical dislocation or $\mathrm{CO}_{2}$ inhalation and decapitation between 8 and 10 AM.

Preparation of isolated adipose cells and measurement of cell size. Immediately after the animals were killed, the whole epididymal fat pads were removed and isolated adipose cells were prepared by the method originally described by Rodbell (15) and subsequently modified by Cushman (16) using crude collagenase (Cooper Biomedical, Malvern, PA). All incubations were carried out in Krebs-Ringer-bicarbonate buffer reduced to $10 \mathrm{mM} \mathrm{HCO}_{3}^{-}$and supplemented with 30 mM Hepes (Sigma Chemical Co., St. Louis, MO), pH 7.4, $37^{\circ} \mathrm{C}$, containing $1 \%$ untreated BSA (bovine serum albumin powder, Fraction V; Reheis Chemical Co., Kankakee, IL). Adipose cell size was determined by the osmic acid fixation, Coulter Electronic Counter method (Coulter Instruments, Hialeah, FL) (Method III) described by Hirsch and Gallian (17) for intact tissue fragments, and modified for isolated cell suspensions by Cushman and Salans (18).

Measurement of adipose cell glucose transport activity and intracellular water space. Isolated adipose cells from a minimum of eight rats for each experimental group were incubated at $37^{\circ} \mathrm{C}$ for $30 \mathrm{~min}$ in the presence of 0 or $7 \mathrm{nM}(1,000 \mu \mathrm{U} / \mathrm{ml})$ insulin (crystalline porcine zinc insulin, courtesy of Dr. Ronald B. Chance, Eli Lilly and Co., Indianapolis, IN). 3-O-[ $\left[{ }^{14} \mathrm{C}\right]$ methylglucose transport was then assessed using a substrate concentration of $0.1 \mathrm{mM}$ by a modification described by Karnieli et al. (19) of the L-arabinose uptake method of Foley et al. (20). The intracellular water space was assessed as steady-state 3-Omethylglucose uptake levels.

$R N A$ isolation. Isolated adipose cells were prepared as described above and immediately frozen in liquid nitrogen. They were stored at $-70^{\circ} \mathrm{C}$ for $1-3 \mathrm{~d}$ before RNA extraction using the guanadinium thiocyanate- $\mathrm{CsCl}$ technique (21).

Northern gels and slot blots. For Northern gels RNA was electrophoresed on $1.2 \%$ formaldehyde agarose gels (22), blotted and fixed onto nylon filters, and then hybridized to cDNA or RNA probes. For slot blots RNA was blotted and fixed onto nitrocellulose filters and hybridized with a cDNA probe. The cDNA probe for the glucose transporter is a mixture of two ${ }^{32} \mathrm{P}$ nick-translated glucose transporter cDNA fragments that are 450 (GT25S) and 2,400 (pGT25L) base pair Eco RI fragments obtained from Dr. Mike Mueckler. Together the two fragments contain nearly a full-length copy of the mRNA (12). Tubulin cDNA was obtained from Dr. Seth Alper, glycerophosphate dehydrogenase cDNA (23) from Dr. Deborah E. Dobson, actin cDNA from Dr. Kathleen Sue Cook, and adipsin cDNA (24) from Dr. Barry Rosen. All probes were either nick translated using a nick translation kit (Amersham Corp., Arlington Heights, IL) according to instructions specified by the manufacturer or labeled with random priming as previously described $(25,26)$.

Hybridization with cDNA probes was carried out at $42^{\circ} \mathrm{C}$ in a solution comprised of $50 \%$ formamide, $5 \times \operatorname{SSPE}(0.9 \mathrm{M} \mathrm{NaCl}, 5 \mathrm{mM}$ EDTA, and $\left.50 \mathrm{mM} \mathrm{NaH}_{2} \mathrm{PO}_{4}, \mathrm{pH} 7.4\right), 0.2 \% \mathrm{SDS}, 0.1 \%$ each of BSA, polyvinylpyrolidine, and Ficoll and denatured, sheared salmon sperm DNA $(200 \mu \mathrm{g} / \mathrm{ml})$. The probes were included at $10^{7} \mathrm{cpm} / \mathrm{ml}$ (glucose transporter) or $10^{6} \mathrm{cpm} / \mathrm{ml}$ (tubulin, actin, glycerophosphate dehydrogenase, and adipsin). Blots were washed in $1.0 \times$ SSPE and $0.1 \%$ SDS at $24^{\circ} \mathrm{C}$ (three washes of $10 \mathrm{~min}$ each) and then in $0.1 \times$ SSPE and $0.1 \%$ SDS at $50-55^{\circ} \mathrm{C}$ (three washes of $30 \mathrm{~min}$ each). They were then exposed to Kodak XAR-5 film at $-70^{\circ} \mathrm{C}$ for varying time periods as indicated in figure legends (intensifying screen, Cronex Lightening Plus; E. I. DuPont de Nemours Co., Wilmington, DE). The abundance of specific glucose transporter or tubulin message was quantitated using a scanning densitometer (GS 300; Hoefer Scientific Instruments, San Francisco, CA). The areas under the curves were calculated using the Hoefer GS 350 computer program.

For the RNA probe, the Hep G2 glucose transporter cDNA was subcloned into the BAM HI site of the pGEM plasmid (Promega Biotech, Madison, WI) and the antisense RNA was synthesized using $T_{7}$ RNA polymerase (Stratagene, San Diego, CA) and $\left[{ }^{32} \mathrm{P}\right] \mathrm{UTP}(800$ $\mathrm{Ci} / \mathrm{mmol}$ sp act) as described by the manufacturer. The labeled RNA was separated from unincorporated UTP using phenol/chloroform followed by chloroform only extractions and ethanol precipitation. Hybridization to the RNA probe was carried out at $65^{\circ} \mathrm{C}$ in a hybridization solution composed of $50 \%$ formamide, $5 \times$ SSC (SSC is $0.15 \mathrm{M}$ sodium chloride and $0.015 \mathrm{M}$ sodium citrate, $\mathrm{pH} 7.0), 1 \times \mathrm{PE}(\mathrm{PE}$ is 50 $\mathrm{mM}$ Tris, $\mathrm{pH} 7.5,0.1 \%$ sodium pyrophosphate, $1 \% \mathrm{SDS}, 0.2 \%$ polyvinylpyrolidone, $0.2 \%$ Ficoll, 5\% EDTA, $1 \%$ BSA), and $150 \mu \mathrm{g} / \mathrm{ml}$ denatured salmon sperm DNA. The probe was included at $10^{6} \mathrm{cpm} /$ $\mathrm{ml}$. Filters were washed twice in $2 \times \mathrm{SSC}, 0.1 \% \mathrm{SDS}$ at $65^{\circ} \mathrm{C}$ and twice in $0.1 \times \mathrm{SSC}, 0.1 \% \mathrm{SDS}$ at $65^{\circ} \mathrm{C}$ (each wash for $15 \mathrm{~min}$ ) and then exposed to autoradiography.

Calculations and statistical analyses. Calculations of 3-O-methylglucose transport and adipose cell size were carried out on the Dartmouth time-sharing system computer facilities. Statistical analyses were carried out on the Beth Israel Hospital analyzer system using analysis of variance and the Newman-Keuls test. Differences were accepted as significant at the $P \leq 0.05$ level.

\section{Results}

Effects of fasting and refeeding on glucose transport activity in adipose cells. The effects of $3 \mathrm{~d}$ of fasting and of $2 \mathrm{~d}$ of fasting followed by $6 \mathrm{~d}$ of refeeding on 3-O-methylglucose transport in isolated rat adipose cells are illustrated in Fig. 1. Basal glucose transport activities do not differ, whereas the maximally insulin-stimulated activity is decreased $71 \%$ with fasting and not

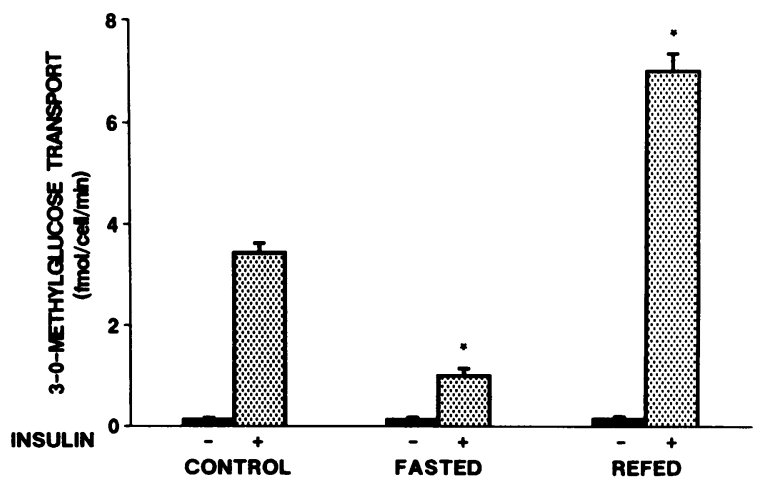

Figure 1. Glucose transport activities in basal and maximally insulinstimulated adipose cells from control, 3-d fasted, and 2-d fasted/6-d refed rats. Isolated cells were prepared from the epididymal fat pads from 8-32 rats in each group, incubated for $30 \mathrm{~min}$ at $37^{\circ} \mathrm{C}$ in the absence or presence of $7 \mathrm{nM}$ insulin, and sampled for measurement of 3-O-methylglucose transport as described in Methods. Results are means \pm SEM of the mean values from at least quadruplicate samples in each of six separate experiments. ${ }^{*}$ Difference from control at $P$ $\leq 0.05$. 
Table I. Characteristics of Adipose Cells from Control, 3-Day Fasted and 2-Day Fasted/6 Day Refed Rats

\begin{tabular}{lccc}
\hline & Control & Fasted & Refed \\
\hline $\begin{array}{l}\text { Adipose cell size } \\
(\mu \mathrm{g} \text { lipid/cell) }\end{array}$ & $0.13 \pm 0.01$ & $0.08 \pm 0.01^{*}$ & $0.12 \pm 0.01$ \\
$\begin{array}{c}\text { Adipose cell intracellular } \\
\text { water (pl/cell) }\end{array}$ & $2.09 \pm 0.08$ & $1.55 \pm 0.13^{*}$ & $2.97 \pm 0.08^{*}$ \\
\hline
\end{tabular}

Rats were fasted and refed as described in Methods. Adipose cell size and intracellular water were determined on pooled cells from 8-32 rats in each group in each of the 6 experiments described in Fig. 1. Results of cell size and intracellular water are means \pm SEM of individual means from duplicate (for cell size) or quadruplicate (for intracellular water) samples in the six separate experiments. ${ }^{*}$ Difference from control at $P \leq 0.05$.

only restored, but increased to two times the control level with refeeding. These results confirm our previous observations (4).

Effects of fasting and refeeding on adipose cell size, intracellular water, and total RNA. Adipose cell size is reduced $38 \%$ and intracellular water $26 \%$ with fasting (Table I). $6 \mathrm{~d}$ of refeeding after $2 \mathrm{~d}$ of fasting is associated with an increase in cell size, although it remains slightly less than control, whereas intracellular water increases to $42 \%$ greater than control. In parallel with the changes in intracellular water, total RNA/cell decreases $35 \%$ with fasting and increases to $82 \%$ greater than control with refeeding (Fig. $2 A$ ). Total RNA/water space remains relatively constant (Fig. $2 \mathrm{~B}$ ).

Effects of fasting and refeeding on specific mRNA levels. Probing Northern blots of total adipose cell RNA with either the Hep G2 glucose transporter cDNA or antisense RNA under stringent conditions yields a single $2.8-\mathrm{kb}$ transcript (Fig. 3), the size of which is unaltered by fasting or refeeding. The abundance of transcript/cell is decreased $36 \%$ in cells from fasted rats and restored to control levels or slightly above in cells from refed rats (Fig. $4 \mathrm{~A}$ ). Even greater changes are seen with tubulin mRNA/cell, which is decreased $68 \%$ with fasting
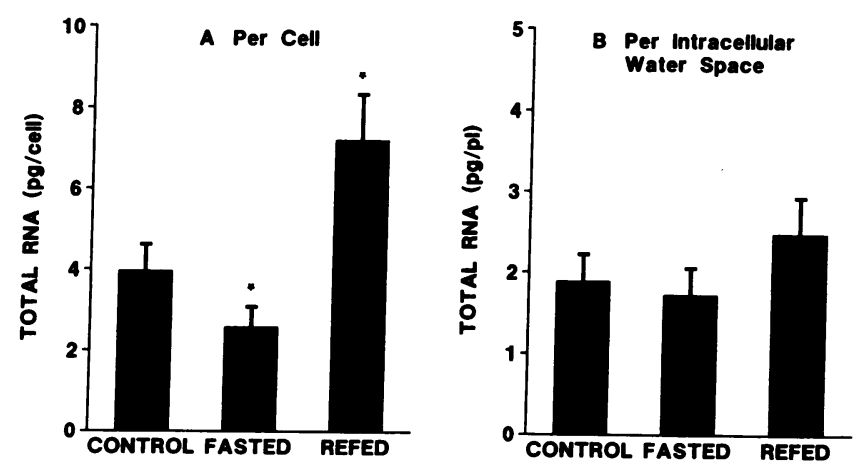

Figure 2. Total RNA per cell $(A)$ and per intracellular water space $(B)$ in adipose cells from control, 3-d fasted, and 2-d fasted/6-d refed rats. Isolated cells were prepared as described in Fig. 1, aliquots were removed for measurement of 3-O-methylglucose transport and cell size, and RNA was extracted as described in Methods. Intracellular water space was determined as the steady-state 3-O-methylglucose uptake levels. Results are means \pm SEM of the mean values of duplicate or triplicate samples in each of six separate experiments. ${ }^{*}$ Difference from control at $P \leq 0.05$.
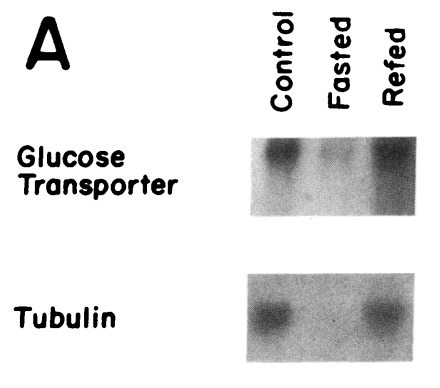

Actin

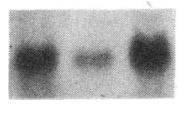

Glycero phosphate Dehydrogenase

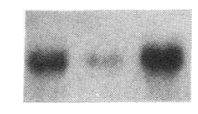

Adipsin

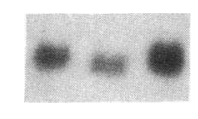

$B$

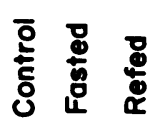

Glucose Transporter

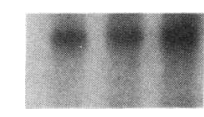

Tubulin

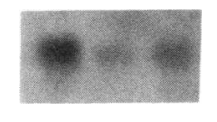

Figure 3. Detection of specific mRNA in adipose cells from control, 3-d fasted and 2-d fasted/6-d refed rats by Northern gel blot analyses. RNA was extracted as described in Fig. 2 and Northern analysis was performed as described in Methods. In $A$ amounts of RNA representing equivalent numbers of cells were loaded; for control $25 \mu \mathrm{g}$, for fasted $10.5 \mu \mathrm{g}$ and for refed $45.8 \mu \mathrm{g}$. In $B, 25 \mu \mathrm{g}$ of RNA was loaded in each lane. Blots were hybridized with a riboprobe for the glucose transporter, a nick translated cDNA probe for tubulin and random primed cDNA probes for actin, glycerophosphate dehydrogenase (GPD) and adipsin as described in Methods. Autoradiograms were exposed for 7 d for the glucose transporter, 3 $\mathrm{d}$ for tubulin, $6 \mathrm{~h}$ for actin, 40 $\mathrm{h}$ for GPD, and $20 \mathrm{~h}$ for adipsin at $-70^{\circ} \mathrm{C}$. These blots are representative of six experiments for the glucose transporter, four for tubulin and three for actin, GPD, and adipsin. and restored close to normal with refeeding (Fig. $4 \mathrm{~B}$ ). The changes in mRNA abundance of actin, glycerophosphate dehydrogenase, a key lipogenic enzyme, and adipsin, a serine protease secreted by adipose cells, are similar to those seen with tubulin (Fig. 3).

\section{Discussion}

Glucose transporter number in adipose cell membrane fractions has previously been shown to decrease with fasting and return to normal with refeeding (4). When the numbers of transporters in the plasma membrane and low density microsomal fractions are summed, an $\sim 50 \%$ decrease in total cellular glucose transporters can be estimated with $2 \mathrm{~d}$ of fasting and a restoration to control levels with $6 \mathrm{~d}$ of refeeding (4) (Fig. 5). $3 \mathrm{~d}$ of fasting may be associated with an even greater loss of transporters since insulin-stimulated glucose transport activity is decreased even further than after $2 \mathrm{~d}$ of fasting (4). In this study, we show that changes in glucose transporter mRNA abundance correlate closely with these alterations in glucose transporter number. However, these changes are evident only when substantial concurrent alterations in total RNA/cell are taken into account. Since the mRNAs encoding cytoskeletal proteins such as tubulin and actin are also markedly altered, these mRNAs cannot be used to normalize other specific mRNAs. In addition, the expression of several genes that have 

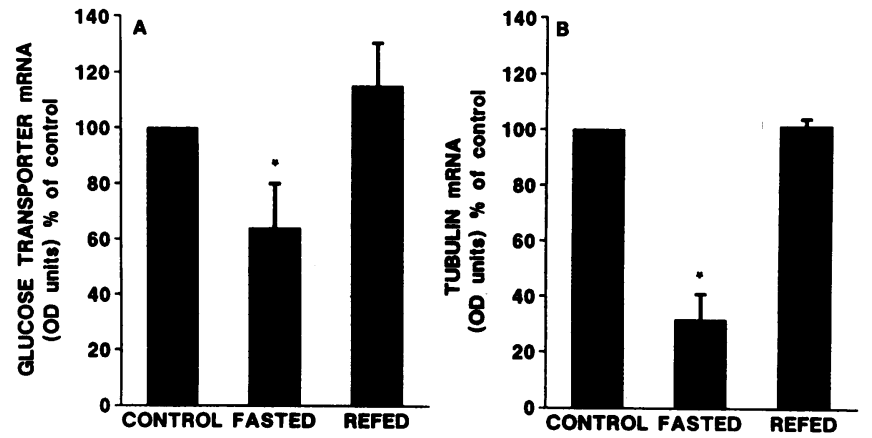

Figure 4. Abundance of glucose transporter $(A)$ and tubulin $(B)$ mRNAs in adipose cells from control, 3-d fasted and 2-d fasted/6-d refed rats. RNA was extracted as described in Fig. 2. Northern or slot blot analyses, hybridization with glucose transporter and tubulin cDNAs and riboprobes and quantitative densitometry were performed as described in Methods. Abundance of glucose transporter or tubulin mRNA per cell was determined both by $(a)$ loading equal amounts of total RNA from each group of cells and calculating OD units per cell and $(b)$ loading amounts of RNA which corresponded to equivalent numbers of cells and directly measuring OD per cell. Results are means \pm SEM of values from six and four separate experiments for the glucose transporter and tubulin, respectively. ${ }^{*}$ Difference from control at $P \leq 0.05$.

been shown to be differentiation dependent in 3T3-F442A adipose cells $(23,24)$ and to be highly expressed in mammalian adipose cells is significantly affected by fasting and refeeding (Fig. 3).

The decrease in total RNA/adipose cell (Fig. $2 \mathrm{~A}$ ) that we observe with fasting in this study is probably part of a more generalized response to starvation that affects multiple tissues as previously demonstrated by Goodman and Ruderman (27) in liver, heart, soleus muscle, and extensor digitorium longus.

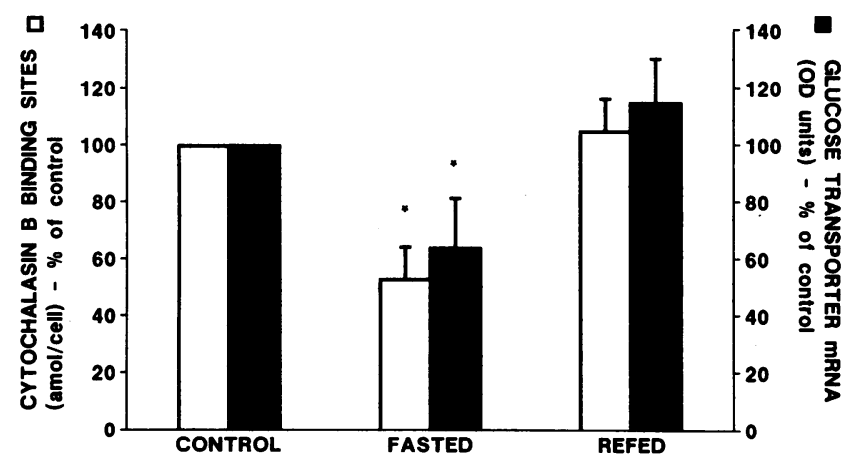

Figure 5. Comparison between the number of glucose transporters and glucose transporter mRNA levels in adipose cells from control, 2-3-d fasted and 2-d fasted/6-d refed rats. Data for glucose transporter number are derived from measurements published in reference 4. Glucose transporter concentrations determined by cytochalasin B binding in subcellular membrane fractions (19) were multiplied by the $\mathrm{mg}$ of protein in the respective membrane fractions (36). Values for plasma membranes and low-density microsomes were summed to estimate a total number of glucose transporters per cell. Glucose transporter mRNA data are from Fig. $4 \mathrm{~A}$. For each experiment the results in cells from fasted and refed rats are expressed as a percentage of the corresponding control. Results are means \pm SEM of four separate experiments for fasting and six for refeeding. *Difference from control at $P \leq 0.05$.
Although these changes in total tissue or cellular RNA largely reflect changes in ribosomal RNA, the latter appears to be paralleled by a fall in the levels of multiple specific mRNAs as illustrated here for tubulin, actin, glycerophosphate dehydrogenase and adipsin as well as the glucose transporter (Fig. 3). In our previous studies, we demonstrated that fasting was associated with a $30 \%$ decrease in total protein per adipose cell, the majority of which was intracellular protein (4). This corresponds to the $26 \%$ decrease in intracellular water space, a reflection of cytosolic mass, observed in this study (Table I). Refeeding, on the other hand, was associated with a $60 \%$ increase in total protein/cell, all of which was intracellular. Again this is reflected in the $82 \%$ increase in intracellular water space observed here (Table I). While the amount of total RNA/cell decreases substantially with fasting and increases significantly above control levels with refeeding (Fig. $2 A$ ), the amount per intracellular water space does not change significantly (Fig. $2 \mathrm{~B}$ ). Thus, the abundance of total cellular RNA appears to vary in concert with the amount of intracellular protein.

These changes in total RNA/cell must be taken into account when investigating the relative abundance of specific mRNA species in cells from fasted or refed rats. Usually with Northern blot hybridization studies, one probes equivalent amounts of total RNA in each lane of a gel, since total RNA content/cell generally remains constant. However, we have shown dramatic changes in total adipose cell RNA with fasting and refeeding and consequently, the same amount of RNA reflects a different number of cells. Therefore, probing equivalent amounts of total RNA will be misleading when the most physiologically meaningful result is the abundance of a specific message per cell. For that reason, we have expressed our data per cell either by calculating the optical density units per cell from the values obtained from equivalent amounts of RNA (Fig. $4 A$ and $B$ ) or by loading agarose gels with amounts of RNA that correspond to equivalent numbers of cells (Fig. 3). The results of both approaches are very similar.

Studies to date aimed at determining the mechanism(s) for insulin resistant and hyperresponsive glucose transport activity have focused on the changes in glucose transporter number and distribution in subcellular membrane fractions (19, 28-30) and more recently, on the intrinsic activity (glucose turnover number) of the glucose transporter (4, 6-11). Insulin appears to stimulate glucose transport in adipose cells and muscle by recruiting glucose transporter proteins from an intracellular pool associated with the low density microsomes to the plasma membrane $(19,28,31)$. In multiple insulin resistant states in animals (28) the intracellular pool of glucose transporters is reduced and thus fewer are translocated to the plasma membrane in response to insulin. In contrast, both increased glucose transporter number (29) and intrinsic activity $(6,7)$ appear to be involved in states of insulin-hyperresponsive glucose transport.

An increase in the number of glucose transporters could be brought about by changes in the half-life of the transporter protein or by an increase in the synthesis rate of the transporter associated with more abundant glucose transporter mRNA. Both mechanisms have been shown to be operable in studies in cultured cells in which glucose transport is increased by oncogene transformation (32-34) or glucose starvation $(34,35)$. We demonstrate that the abundance of glucose transporter specific mRNA in adipose cells from fasted and refed rats 
(Figs. 3 and $4 A$ ) correlates closely with the number of glucose transporters as measured previously by cytochalasin $B$ binding and Western blotting (4) (Fig. 5). In the case of fasting, this also corresponds qualitatively with the reduction in insulin-stimulated glucose transport activity per cell. In the case of refeeding, a discordance between glucose transporter number in the subcellular membrane fractions and glucose transport activity in the intact adipose cell has previously been demonstrated and appears to result from an increase in glucose transporter intrinsic activity (4). Therefore, the lack of correlation of the mRNA abundance with cellular glucose transport activity in this state is the expected result. These data provide evidence for the possibility that the changes in glucose transporter number, and thus in the glucose transport response to insulin, in adipose cells from animals and humans with altered nutritional and metabolic states may be regulated by the abundance of glucose transporter specific mRNA. Whether this is due to increased transcription or increased mRNA stability deserves further investigation.

Recent studies demonstrate biochemical heterogeneity of the glucose transporter protein(s) in adipose cells as evidenced by differences in affinity for cytochalasin $\mathbf{B}(36,37)$, immunoreactivity $(38,39)$, isolectric focusing points $(37,40)$, and susceptibility to neuraminidase, which desialates terminally glycosylated proteins (40). The theoretical possibility that multiple genetically distinct glucose transporters are expressed in adipose cells has recently been raised by the identification of a glucose transporter in liver, which is only $55 \%$ homologous with the rat brain and the Hep G2 cDNA protein product (41, 42). However, this species is not present in adipose cells (42) and currently no definitive evidence indicates that the biochemical heterogeneity of the adipose cell transporter proteins reflects differences in amino acid sequence or gene structure.

In the absence of data identifying other genetically distinct glucose transporters in adipose cells, the Hep G2/brain probe is a logical starting point to investigate the regulation of glucose transporter number. This cDNA has proved valuable for studying the mechanism(s) by which glucose transporter number and glucose transport activity are increased in cultured fibroblasts in response to certain oncogenes $(32,33)$ and phorbol esters (32). Additionally, similar antibodies to those used to identify the Hep G2 cDNA probe have been shown to cross-react with the glucose transporter in adipose cells and have been used as a semiquantitative assay of glucose transporter number $(4,38,43)$. In fact, the close correlation demonstrated here between alterations in glucose transporter number and mRNA abundance in adipose cells from fasted and refed rats (Fig. 5) is consistent with the hypothesis that the single mRNA species detected at high stringency with the Hep G2 cDNA probe encodes the major insulin-responsive adipose cell glucose transporter. If a distinct but sufficiently homologous glucose transporter species were present, the Hep G2 cDNA could hybridize with it as well and techniques other than blot hybridization would be necessary to distinguish such a species.

Thus these studies investigate the effects of specific in vivo nutritional alterations on the expression of a glucose transporter gene and its correlation with glucose transport physiology. Because the mechanism for insulin resistant glucose transport activity in adipose cells from humans with obesity $(8,44)$ and diabetes (8) results, at least in part, from a reduction in the number of glucose transporters, it will be important to determine whether this insulin resistance is also associated with changes in the abundance of this or other glucose transporter mRNAs.

\section{Acknowledgments}

The authors thank Mary Jane Zarnowski for her expert technical assistance, Terri Wiseman and Brian McCarthy for preparing the manuscript, and the following investigators for providing specific cDNAs: Drs. Mike Mueckler, Kathleen Sue Cook, Seth Alper, Deborah E. Dobson, Barry Rosen, and Bruce Spiegelman. This work was supported in part by Juvenile Diabetes Foundation grant 187487 (to Dr. Kahn) and National Institutes of Health grant AM-28082 (to Dr. Flier).

Note added in proof. Recent published $(45,46)$ and unpublished (M. Charron and H. Lodish and D. James and M. Mueckler, personal communications) data suggest that mammalian tissues contain a family of glucose transporters which may be products of distinct genes. At this time we do not know what component of basal and/or activated glucose transport is accounted for by the Hep G2/rat brain glucose transporter, nor whether the mRNA(s) detected using this cDNA under stringent hybridization conditions encode more than one species of glucose transporter proteins with different functional activities.

\section{References}

1. Olefsky, J. M. 1976. Effects of fasting on insulin binding, glucose transport and glucose oxidation in isolated rat adipocytes. J. Clin. Invest. 58:1450-1460.

2. Kasuga, M., Y. Akanuma, Y. Iwamoto, and K. Kosaka. 1977. Effects of fasting and refeeding on insulin receptors and glucose metabolism in rat adipocytes. Endocrinology. 100:1384-1390.

3. Owens, J. L., D. Thompson, N. Shah, and M. DiGirolamo. 1979. Effects of fasting and refeeding in the rat on adipocyte metabolic functions and response to insulin. J. Nutr. 109:1584-1591.

4. Kahn, B. B., I. A. Simpson, and S. W. Cushman. 1988. Divergent mechanisms for the insulin resistant and hyperresponsive glucose transport in adipose cells from fasted and refed rats: alterations in both glucose transporter number and intrinsic activity. J. Clin. Invest. 82: 691-699.

5. Pedersen, O., E. Hjollund, and N. S. Sorensen. 1982. Insulin receptor binding and insulin action in human fat cells: effects of obesity and fasting. Metab. Clin. Exp. 31:884-895.

6. Kahn, B. B., and S. W. Cushman. 1987. Mechanism for markedly hyperresponsive insulin-stimulated glucose transport activity in adipose cells from insulin-treated streptozotocin diabetic rats: evidence for increased glucose transporter intrinsic activity. J. Biol. Chem. 262:5118-5124.

7. Karnieli, E. M. Armoni, P. Cohen, Y. Kanter, and R. Rafaeloff. 1987. Reversal of insulin resistance in diabetic rat adipocytes by insulin therapy: restoration of pool of glucose transporters and enhancement of glucose transporter activity. Diabetes. 36:925-931.

8. Garvey, W. T., T. P. Huecksteadt, S. Matthaei, and J. M. Olefsky. 1987. Role of glucose transporters in the cellular insulin resistance of Type II non-insulin-dependent diabetes mellitus. J. Clin. Invest. 78:1051-1055.

9. Smith, U., M. Kuroda, and I. A. Simpson. 1984. Counterregulation of insulin-stimulated glucose transport by catecholamines in the isolated rat adipose cell. J. Biol. Chem. 259:8758-8763.

10. Joost, H. G., T. M. Weber, S. W. Cushman, and I. A. Simpson. 1986. Insulin-stimulated glucose transport in rat adipose cells: modulation of transporter intrinsic activity by isoproterenol and adenosine. J. Biol. Chem. 261:10033-10036.

11. Kuroda, M., R. C. Honnor, S. W. Cushman, C. Londos, and I. A. Simpson. 1987. Regulation of insulin-stimulated glucose transport in the isolated rat adipocyte: cAMP-independent effects of lipolytic and antilipolytic agents. J. Biol. Chem. 262:245-253. 
12. Mueckler, M. M., C. Caruso, S. A. Baldwin, M. Panico, I. Blench, H. R. Morris, J. W. Allard, G. E. Lienhard, and H. F. Lodish. 1985. Sequence and structure of a human glucose transporter. Science (Wash. DC). 229:941-945.

13. Birnbaum, M. J., H. C. Haspel, and O. M. Rosen. 1986. Cloning and characterization of a cDNA encoding the rat brain glucosetransporter protein. Proc. Natl. Acad. Sci. USA. 83:5784-5788.

14. Flier, J. S., M. Mueckler, A. L. McCall, and H. F. Lodish. 1987. Distribution of glucose transporter messenger RNA transcripts in tissues of rat and man. J. Clin. Invest. 79:657-661.

15. Rodbell, M. 1964. Metabolism of isolated fat cells. I. Effects of hormones on glucose metabolism and lipolysis. J. Biol. Chem. 239:375-380.

16. Cushman, S. W. 1970. Structure-function relationship in the adipose cell. I. Ultrastructure of the isolated adipose cell. J. Cell Biol. 46:326-341.

17. Hirsch, J., and E. Gallian. 1968. Methods for determination of adipose cell size in man and animals. J. Lipid Res. 9:110-119.

18. Cushman, S. W., and L. B. Salans. 1978. Determination of adipose cell size and number in suspensions of isolated rat and human adipose cells. J. Lipid Res. 19:269-273.

19. Karnieli, E., M. J. Zarnowski, P. J. Hissin, I. A. Simpsom, L. B. Salans, and S. W. Cushman. 1981. Insulin-stimulated translocation of glucose transport systems in the rat adipose cell. Time course, reversal, insulin concentration-dependency and relationship to glucose transport activity. J. Biol. Chem. 256:4772-4777.

20. Foley, J. E., S. W. Cushman, and L. B. Salans. 1978. Glucose transport in isolated rat adipocytes with measurements of $\mathrm{L}$-arabinose uptake. Am. J. Physiol. 234:E112-E119.

21. Chirgwin, J. M., A. W. Przybyla, R. J. MacDonald, and W. J. Rutter. 1979. Isolation of biologically active ribonucleic acid from sources enriched in ribonuclease. Biochemistry. 18:5294-5299.

22. Maniatis, T., E. F. Frisch, and J. Sambrook. 1982. Molecular cloning: a laboratory manual. Cold Spring Harbor Laboratory, New York. 202-203.

23. Spiegelman, B. M., M. Frank, and H. Green. 1983. Molecular cloning of mRNA from 3T3 adipocytes. Regulation of mRNA content for glycerophosphate dehydrogenase and other differentiation-dependent proteins during adipocyte development. J. Biol. Chem. 258:100083-100089.

24. Cook, K. S., D. L. Groves, H. Y. Min, and B. M. Spiegelman. 1985. A developmentally regulated mRNA from 3T3 adipocytes encodes a novel serine protease homologue. Proc. Natl. Acad. Sci. USA. 82:6480-6484.

25. Feinberg, A. P., and B. Vogelstein. 1985. A technique for radiolabeling DNA restriction endonuclease fragments to high specific activity. Anal. Biochem. 132:6-13.

26. Feinberg, A. P., and B. Vogelstein. 1984. A technique for radiolabeling DNA restriction endonuclease fragments to high specific activity. Addendum. Anal. Biochem. 137:266-267.

27. Goodman, M. N., and N. B. Ruderman. 1980. Starvation in the rat. I. Effect of age and obesity on organ weights, RNA, DNA, and protein. Am. J. Physiol. 239:E269-E276.

28. Kahn, B. B., and S. W. Cushman. 1985. Subcellular translocation of glucose transporters: role in insulin action and its perturbation in altered metabolic states. Diabetes/Metab. Rev. 1:203-227.

29. Kahn, B. B., E. S. Horton, and S. W. Cushman. 1987. Mechanism for enhanced glucose transport response to insulin in adipose cells from chronically hyperinsulinemic rats: increased translocation of glucose transporters from an enlarged intracellular pool. J. Clin. Invest. 79:854-859.

30. Wardzala, L. J., and B. Jeanrenaud. 1981. Potential mechanism of insulin action on glucose transport in isolated rat diaphragm: appar- ent translocation of intracellular transport systems to the plasma membrane. J. Biol. Chem. 256:7090-7093.

31. Suzuki, K., and T. Kono. 1980. Evidence that insulin causes translocation of glucose transport activity to the plasma membrane from an intracellular storage site. Proc. Natl. Acad. Sci. USA. 77:2542-2545.

32. Flier, J. S., M. M. Mueckler, P. Usher, and H. F. Lodish. 1987. Elevated levels of glucose transport and transport messenger RNA are induced by ras or src oncogenes. Science (Wash. DC). 235:1492-1495.

33. Birnbaum, M. J., H. C. Haspel, and O. M. Rosen. 1987. Transformation of rat fibroblasts by FSV rapidly increases glucose transporter gene transcription. Science (Wash. DC). 235:1495-1498.

34. Shawver, L. K., S. A. Olson, M. K. White, and M. J. Weber 1987. Degradation and biosynthesis of the glucose transporter protein chicken in embryo fibroblasts transformed by the src oncogene. Mol. Cell. Biol. 7:2112-2118.

35. Haspel, H. C., E. W. Wilk, M. T. Birnbaum, S. W. Cushman, and O. M. Rosen. 1986. Glucose deprivation and hexose transporter polypeptides of murine fibroblasts. J. Biol. Chem. 261:6778-6789.

36. Simpson, I. A., D. R. Yver, P. J. Hissin, L. J. Wardzala, E. Karnieli, L. B. Salans, and S. W. Cushman. 1983. Insulin-stimulated translocation of glucose transporters in the isolated rat adipose cell: characterization of subcellular fractions. Biochim. Biophys. Acta. 763:393-407.

37. Simpson, I. A., and S. W. Cushman. 1986. Hormonal regulation of mammalian glucose transport. Annu. Rev. Biochem. 55:10591089.

38. Joost, H. G., T. M. Weber, and S. W. Cushman. 1988. Qualitative and quantitative comparison of glucose transport activity and glucose transporter concentration in plasma membranes from basal and insulin-stimulated rat adipose cells. Biochem. J. 249:155-161.

39. James, D. E., R. Brown, J. Navarro, and P. F. Pilch. 1988. Insulin-regulatable tissues express a unique insulin-sensitive glucose transport protein. Nature (Lond.). 333:183-185.

40. Horuk, R., S. Matthaie, J. M. Olefsky, D. L. Baly, S. W. Cushman, and I. A. Simpson. 1986. Biochemical and functional heterogeneity of rat adipocyte glucose transporters. J. Biol. Chem. 261:18231828

41. Fukumoto, H., S. Seino, H. Imura, Y. Seino, R. L. Eddy, Y. Fukushima, M. G. Byers, T. B. Shows, and G. I. Bell. 1988. Sequence, tissue distribution, and chromosomal localization of mRNA encoding a human glucose transporter-like protein. Proc. Natl. Acad. Sci. USA. 85:5434-5438.

42. Thorens, B., H. K. Sarkar, H. R. Kaback, and H. F. Lodish. 1988. Cloning and functional expression in bacteria of a novel glucose transporter present in liver, kidney and $\beta$-pancreatic islet cells. Cell. 55:281-290.

43. Wheeler, T. J., I. A. Simpson, D. C. Sogin, P. C. Hinkle, and S. W. Cushman. 1982. Detection of the rat adipose cell glucose transporter with antibody against the human red cell glucose transporter. Biochem. Biophys. Res. Commun. 105:89-95.

44. Karnieli, E., A. Barzilai, R. Rafaeloff, and M. Armoni. 1986. Distribution of glucose transporters in membrane fractions isolated from human adipose cells. Relation to cell size. J. Clin. Invest. 78:1051-1055.

45. Oka, Y., T. Asano, Y. Shibasaki, M. Kasuga, Y. Kanazawa, and F. Takaku. 1988. Studies with antipeptide antibody suggest the presence of at least two types of glucose transporter in rat brain and adipocyte. J. Biol. Chem. 263:13432-13439.

46. Kayano, T., H. Fukumoto, R. L. Eddy, Y. Fan, M. G. Byers, T. B. Shows, and G. I. Bell. 1988. Evidence for a family of human glucose transporter-like proteins. J. Biol. Chem. 263:15245-15248. 